\title{
プリント基板プローブを用いたTDRと画像解析 による不飽和- 不均一場における水分動態解析 WATER INFILTRATION INVESTIGATIONS IN UNSATURATED-HETEROGENEOUS FIELD BY TDR METHOD USING PRINTED CIRCUIT BOARD PROBE AND BY IMAGE ANALYSIS
}

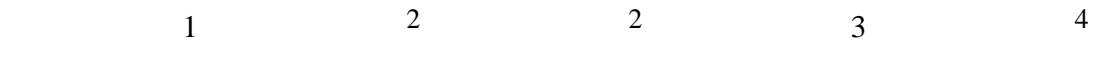 \\ Kei NAKAGAWA, Yoji SEKIOKA, Yosuke MAEKAWA, Kazuro MOMII and Ryosuke KITAMURA

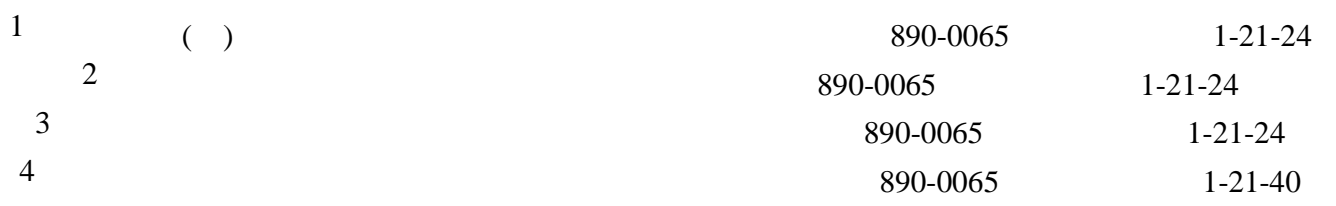

Hydrogeological parameters of field soil porous media are distributed with large heterogeneity. Evaluation of physical heterogeneity effects on soil water flow is important to understand basic flow characteristics of field soil. In this study, two types of water infiltration experiments were applied to examine water flow under the heterogeneous distribution of hydraulic conductivities. Time series of soil water change was measured by time domain reflectometry (TDR). In the TDR system, the small printed circuit board probes (PCBP) were used as wage guide. To evaluate soil water distribution change in the experimental sand box, the simple image analysis of digital photo of the experiments was proposed and tested. According to the TDR measurement, probes show clear response for ponding timing in the stepwise ponding experiment. Once soils were filled with water, they kept water in the continuous infiltration experiment using rain generator. The order of breakthrough match sequential photo of the continuous infiltration experiment. Preferential flow was clearly observed in the both experiments.

Key Words: infiltration, unsaturated-heterogeneous field, TDR method, image analysis

\section{1 .はじめに}

一般に, 現場の土猿や地層における水文地質学的 特性は, 大きな不均一性を持つことが知られている。 この水文地質学的特性の不均一性は, 透水係数のよ うな物理的性質の不均一性として，媒体を流れる水 と炎れに伴う物質輸送へ影響を及ぼすと考えられる。 これまでに多くの研究者が, 透水係数などの物理的 不均一性を含む土壤や地層中の地下水流れを，理論 的, 実験的, また数值計算により研究を行っている 1)-3). Wildenschild and Jensenは，2 次元の透水係数の 不均一場における流れについて，実験および数値計 算により検討し，不均一場を光れと等価な均一場に 置き換えたときの透水係数や不飽和パラメータにつ いて検討した ${ }^{4), 5)}$. 著者らは不飽和-不均一多孔媒体 における物質輸送特性を調べるため, 室内実験と数 値計算を行い比較したが, 両者はあまり一致せずよ り精度の高い室内実験の実施が求められた ${ }^{6)}$. した がって, 局所的な土壤水分の変動や全体的な土㥽水 分の変化に関する実験データはあまり公開されてお
らず, 透水係数が水の浸透過程に及ぼす影響を詳細 に検討するには未だ十分でないと考えられる．

本研究では, 飽和透水係数が不均一に分布する場 を想定し , 地表面からの水の浸透挙動を調べるため の室内実験を実施した 8 つの測定点では，プリン 卜基板製の小型プローブを用いたTDR測定により， 土壤水分量の時間変化を測定した．また非破壊で簡 便な室内実験における土壤水分量の推定方法として， デジタルカメラにより撮影された写真から水分量を 推定する方法を検討した .

\section{2 . 実験の概要}

図-1に実験装置の概略を示す，採取してきた試料 (農場廃土および砂) を炉乾燥させ，5 種類の粒径 範囲 $(\mathrm{a}: 0.1 \sim 0.2, \mathrm{~b}: 0.2 \sim 0.4, \mathrm{c}: 0.4 \sim 0.6, \mathrm{~d}: 0.6 \sim 0.8$, $\mathrm{e}: 0.8 \sim 1.2 \mathrm{~mm})$ に管い分け, 光れ光れ10\%の含水比 に調整した．室内試験により求めた，各粒径範囲の 飽和透水係数を表-1に示す. 


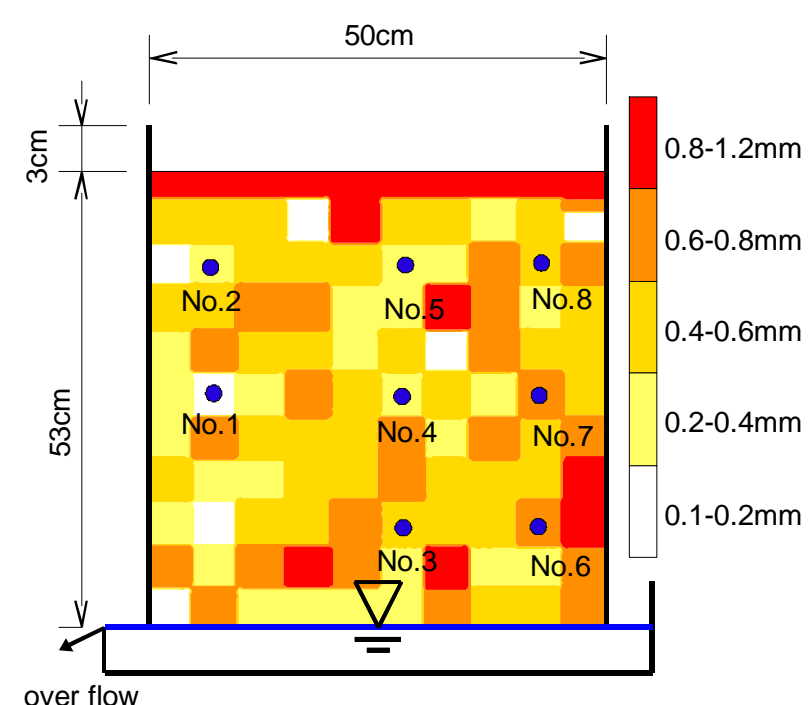

図- 1 実験装置の概略

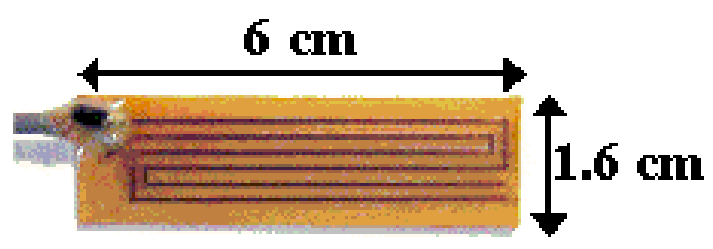

図- 2 プリント基板製TDRプローブ (PCBP)

試料a〜cは農場廃土で, 乾燥密度 $0.9 \mathrm{~g} \mathrm{~cm}^{-3}$ (後の実 験A) または $1.1 \mathrm{~g} \mathrm{~cm}^{-3}$ (後の実験B) に, 試料d, eは 砂で, 乾燥密度 $1.3 \mathrm{~g} \mathrm{~cm}^{-3}$ となるように締め固め, 浸透層の所定の位置へ, 5 × 5 x $10 \mathrm{~cm}$ のブロック毎 に均一に充填した . なお試料充填の際の乾燥密度が 異なるのは，後の実験Aで多少試料の移動が起こっ たため，実験Bでは若干固めに締め固めたからであ る。浸透層内の不均一場は， PMWIN $^{7)}$ の Random Field Generatorを用い, 自然対数変換した飽和透水 係数分布の平均値を -1.05 , 標準偏差を 0.45 , 相関距

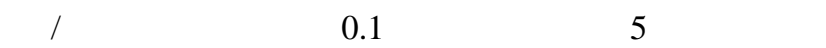
水係数の範囲に分類し作成した. 図-2に示すプリン 卜基盤製のTDRプローブ (PCBP)を ${ }^{6), 8)}$ ，図-1に示す 浸透層内の 8 点に挿入した. TDRのケーブルテスタ は，TDR100 (キャンベル)を用い, マルチプレクサ を介しPCBPと接続した . 浸透層下端には水位を固 定した水面を設けた。

浸透実験は，段階的湛水と降雨発生装置により着 色した水道水を浸透させた (乥れ光れ実験AおよびB

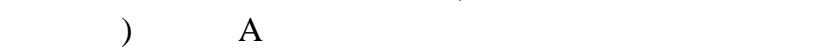
(赤色102号，キリヤ化学)により着色した水道水の $3000 \mathrm{~cm}^{3}$ を段階的に湛水し，浸透させた .すなわち， 前回に湛水させ，浸透した浸潤前線がほぼ停止した 後，次の湛水を行うことを繰り返した . 実験Bでは， 実験 $\mathrm{A}$ 同樣に食用色素で着色した水道水を，マイ クロチューブポンプにより浸透層上部より降雨状に 連続的に散水し, 浸透させた .このときの降雨強度
表- 1 各粒径範囲の透水係数

\begin{tabular}{ccc}
\hline Particle size $/ \mathrm{mm}$ & Hydraulic Conductivity $/ \mathrm{cm} \mathrm{s}^{-1}$ \\
\hline $0.1-0.2$ & $2.3 \times 10^{-3}$ & $1.1 \times 10^{-3}$ \\
$0.2-0.4$ & $5.0 \times 10^{-3}$ & $2.3 \times 10^{-3}$ \\
0.40 .6 & $8.3 \times 10^{-3}$ & $3.2 \times 10^{-3}$ \\
$0.6-0.8$ & $5.6 \times 10^{-2}$ & $5.6 \times 10^{-2}$ \\
0.81 .2 & $8.3 \times 10^{-2}$ & $8.3 \times 10^{-2}$ \\
\hline
\end{tabular}

は， $1.49 \times 10^{-3} \mathrm{~cm} \mathrm{~s}^{-1}$ である.両方の実験における浸 透の樣子は，所定の時間毎にデジタルカメラで撮影 した．またPCBPを挿入した 8 点では，土壤水分

(体積含水率) を算定する為の波形を系時的に測定 した .いずれの実験においても，上部より浸透させ る水が概ね浸透層下部まで浸透したことを確認の後， 実験終了とした .

\section{PCBPを用いたTDRによる土壤水分の変化}

PCBPを用いたTDRによる土壤水分の算定は，次 のようにした . まず, 波形谷のものを256 点の離散 データとしてデータロガーに一時的に保存し，20 分毎に接続したパソコンのハードディスクへ転送し て保存した。実験終了後，記録された波形は光れ光 れWinTDR ${ }^{9)}$ により解析を手動で行い，見かけの誘 電率を作成し，あらかじめ求めておいた試料および PCPB毎の校正曲線により体積含水率へ変換した ${ }^{10)}$

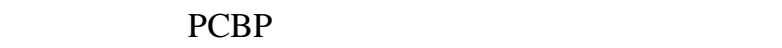
の校正曲線をプロットしたものを図-3に示す．校正 式は，TDRで測定された見かけの誘電率 $\epsilon$ と体積含 水率 $\theta$ の関係式として次式のように求めた . $a \sim d$ は この関係式のパラメータであり，乥れ卆れのPCBP に対する值は表-2に整理している .

$$
\theta=a+b \varepsilon+c \varepsilon^{2}+d \varepsilon^{3}
$$

図中には，Topp et al.の式 ${ }^{11)}$ も示している . Topp et al.のパラメータは, $a=-5.3 \times 10^{-2}, b=2.92 \times 10^{-2}, c=-5.5$ $\mathrm{x} 10^{-4}, d=4.3 \times 10^{-6}$ である.

\section{4 . 画像解析による土猿水分分布の解析}

浸透実験の際にデジタルカメラで撮影した写真か ら，非破壞で体積含水率の分布を簡便に推定するた め, 次のような方法を検討した .すなわち画像処理 ソフトにより撮影された写真のG值から体積含水率 を推定する方法を検討した .ここでもPCBPを用い たTDR法と同樣に，あらかじめ校正曲線を求めてお くことが必要である.含水比を，15, 20, 25, 30, $40 \%$ に調整した各粒径範囲の試料を，実験と同樣の条件 で撮影されたデジタルカメラ写真から中心部を代表 部分としてG值を抽出し, 校正曲線により体積含水 率へ変換する．事前の検討結果よりRGB值のうち G 值が含水比との相関が最も明瞭であったため，ここ 


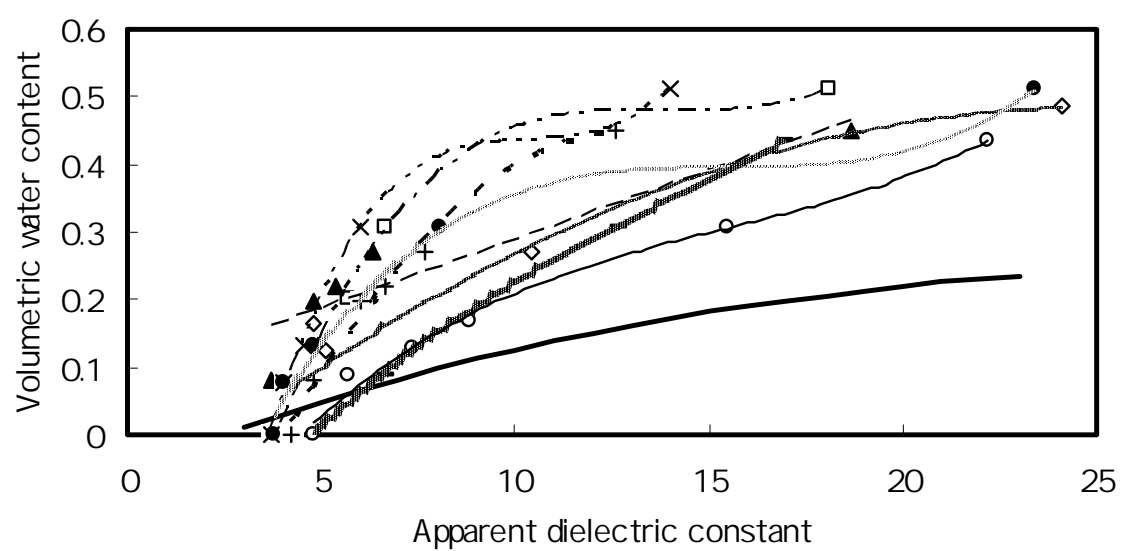

\begin{tabular}{|c|c|c|c|c|c|c|c|}
\hline$\diamond$ & No.1 & $\square$ & No.2 & $\Delta$ & No.3 & $x$ & No.4 \\
\hline$\bullet$ & No.5 & - & No.6 & $\circ$ & No.7 & + & No.8 \\
\hline & -Topp et al. & - & Eq. (No.1) & $-\cdot-$ & - Eq. (No.2) & --- & - Eq. (No.3) \\
\hline _ & $\begin{array}{l}\text { Eq. (No.4) } \\
\text { Eq. (No.8) }\end{array}$ & $\ldots$ & Eq. (No.5) & $=$ & Eq. (No.6) & 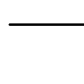 & - Eq. (No.7) \\
\hline
\end{tabular}

図-3PCBPによる見かけの誘電率と体積含水率の関係 (校正曲線)

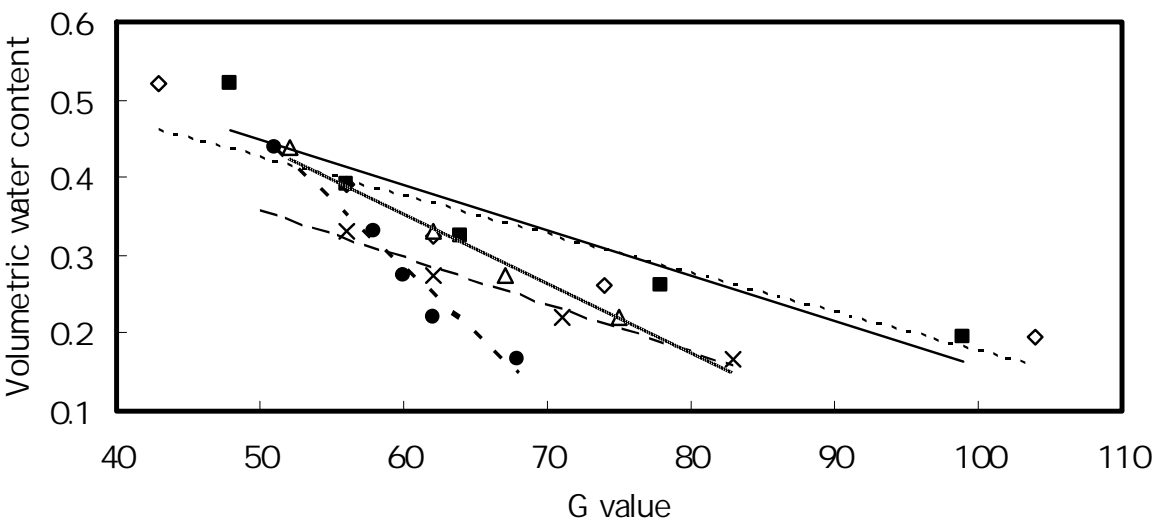

\begin{tabular}{|c|c|c|c|c|}
\hline$\diamond$ & $0.8-1.2 \mathrm{~mm}$ & - $\quad 0.6-0.8 \mathrm{~mm}$ & $\Delta$ & $0.4-0.6 \mathrm{~mm}$ \\
\hline$x$ & $0.2-0.4 \mathrm{~mm}$ & - $\quad 0.1-0.2 \mathrm{~mm}$ & $\cdots$ & · Eq. (0.8- $1.2 \mathrm{~mm})$ \\
\hline & $\begin{array}{l}\text { - Eq. }(0.6-0.8 \mathrm{~mm}) \\
\text { - Eq. }(0.1-0.2 \mathrm{~mm})\end{array}$ & --- Eq. $(0.2-0.4 \mathrm{~mm})$ & - & Eq. $(0.4-0.6 \mathrm{~mm})$ \\
\hline
\end{tabular}

图-4G值と体積含水率の関係 (校正曲線, 実験 $\mathrm{A}$ )

表- 2 TDR測定の校正曲線のパラメータ

\begin{tabular}{ccccc}
\hline \multicolumn{6}{c}{ Probe No. } & $a$ & $b$ & $c$ & $d$ \\
\hline 1 & -0.1184 & 0.0484 & -0.001 & 0 \\
2 & -0.803 & 0.2783 & -0.0201 & 0.0005 \\
3 & -0.0864 & 0.0203 & 0 & 0 \\
4 & -1.1463 & 0.4515 & -0.0432 & 0.0014 \\
5 & -0.4472 & 0.1625 & -0.0104 & 0.0002 \\
6 & 0.3481 & 0.0907 & 0.0044 & 0.0001 \\
7 & -0.3334 & 0.0955 & -0.0053 & 0.0001 \\
8 & -0.5029 & 0.1463 & -0.0056 & 0 \\
\hline
\end{tabular}

ではG值を用いて次式のような校正曲線を作成した .

$$
\theta=0.01 \rho_{d} w=0.01 \rho_{d}(e \mathrm{G}+f)
$$

ここで ${ }_{d}$ は乾燥密度, $w$ は含水比 $(\%), e, f$ は校正曲 線のパラメータで, 各粒径範囲の試料毎に決定する。 $e, f の$ 值は表- 2に示す . 実験写真のブロック毎に平均
表- 3 画像解析の校正曲線のパラメータ

\begin{tabular}{ccc}
\hline Particle size $/ \mathrm{mm}$ & $e$ & $f$ \\
\hline $0.1-0.2$ & -1.5314 & 117.58 \\
$0.2-0.4$ & -0.7086 & 71.631 \\
0.40 .6 & -0.801 & 80.307 \\
$0.6-0.8$ & -0.4486 & 56.956 \\
0.81 .2 & -0.3856 & 52.145 \\
\hline
\end{tabular}

のG值を抽出し，上式により浸透層全体のブロック 単位での体積含水率分布を求める. 図-4に各試料の 実験Aの時の校正曲線を示す . なお推定された体積 含水率の值が負になるときは, 残留体積含水率とな るようにした。 

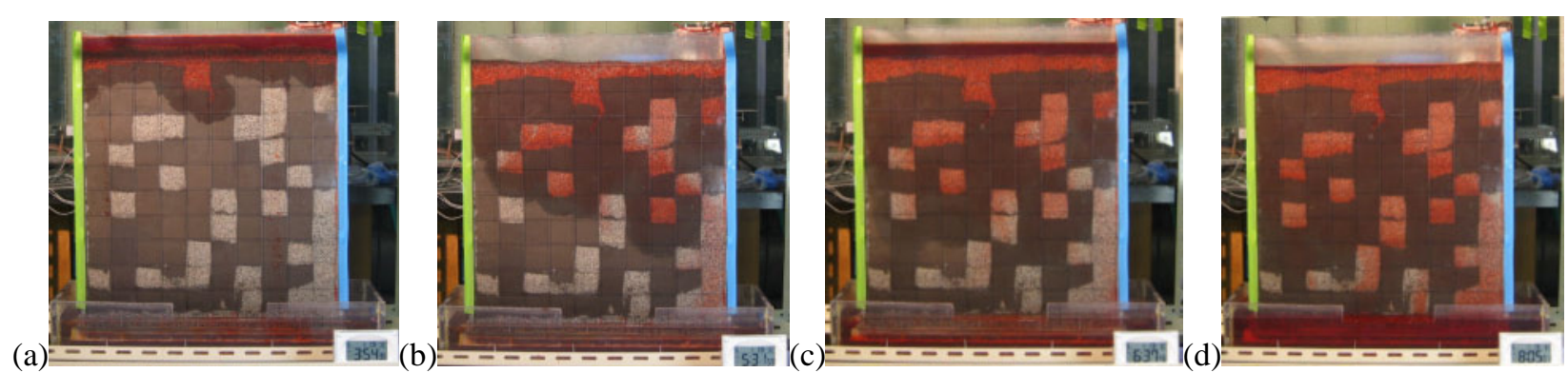

図- 5 実験Aにおける着色した水道水の浸透挙動 (a) 3 min., (b) 120 min., (c) 192 min., (d) 271 min.

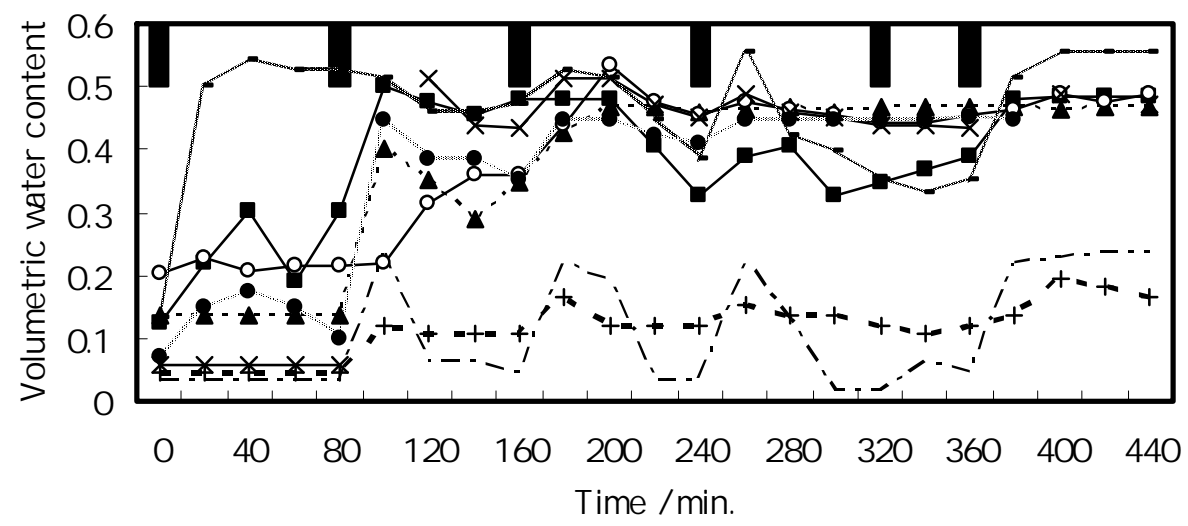

\begin{tabular}{|c|c|c|}
\hline Ponding & $\cdots \Delta-\cdots$ No.1 & $\longrightarrow$ No.2 \\
\hline - No.3 N & $\longrightarrow$ No.4 & $-n=.5$ \\
\hline - -+- - No.6 & $-\cdot--$ No.7 & No.8 \\
\hline
\end{tabular}

図- 6 実験AにおけるPCBP挿入点の体積含水率の変化
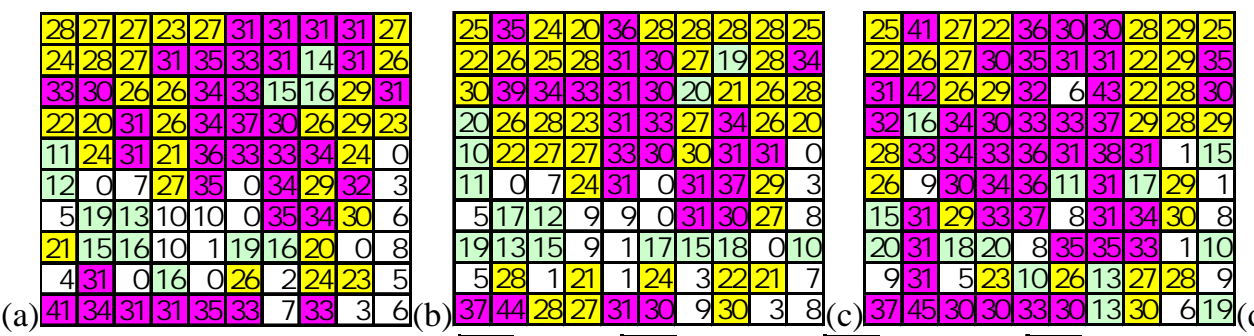

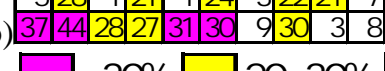

$>30 \% \square 20-30 \%$

$10.20 \% \square<10 \%$

図- 7 実験AにおけるG值により推定した体積含水率分布の変化(\%表示) (a) 3 min., (b) 120 min., (c) 192 min., (d) 271 min.

画像解析による土壤水分量の推定に関しては, Perssonにより，有機物の少ない明るい色の土であれ ば, 土の色と土壌水分量の相関が高いことが示され ている ${ }^{12)}$. これに対し本研究では，着色した水を用 いて試料毎に校正式を作成し，土の色によらない， より簡便な方法として検討した .

\section{5.結果と考察}

\section{（1）段階的湛水実験 (実験A)}

図-5に実験Aにおける着色した水道水の浸透挙動 を示す．初期には，下に凸形に充填された透水係数 の比較的大きい部分のため, 中央部が先行する形で 浸透が進む．弚の後の全体的な流れは，浸透層の右 側へ向かい流下する . これは右側壁面下部に多く配 置された透水係数の大きいブロックのためと考えら れる。
図-6にPCBPを用いたTDRによる各測定点の体積 含水率の変化を示す . 図中には, 湛水の行われたタ イミングも併せて示す.No.6と7の挿入された部分 は, ともに0.6〜0.8 $\mathrm{mm}$ の砂である.この部分では 低い水分量で推移し，砂の保水性を反映しているこ とが分かる. 最初の湛水では, 浸透層上部で保水さ れてしまい, 浸潤前線が到達できず，水分の増加が 見られない.2 回目の湛水により, No.6においては 水分上昇が起こり，以降は低水分量であるが10\%程 度が一定で保水されている樣子が分かる . No.7の方 は, 2 回目以降, 湛水毎に応答はあるものの, 光の 後すぐに水分量の低下が起こっている．この違いは， No.6の周囲のブロックに关れよりも大きい透水係数 を持つブロックが配置されておらず, 兴のため周り に水分を奪われることがなかったことと，No.7のす ぐ右側のブロックは高い透水係数を持ち，このブ ロックを通して排水が促進されたからと考えられる． 

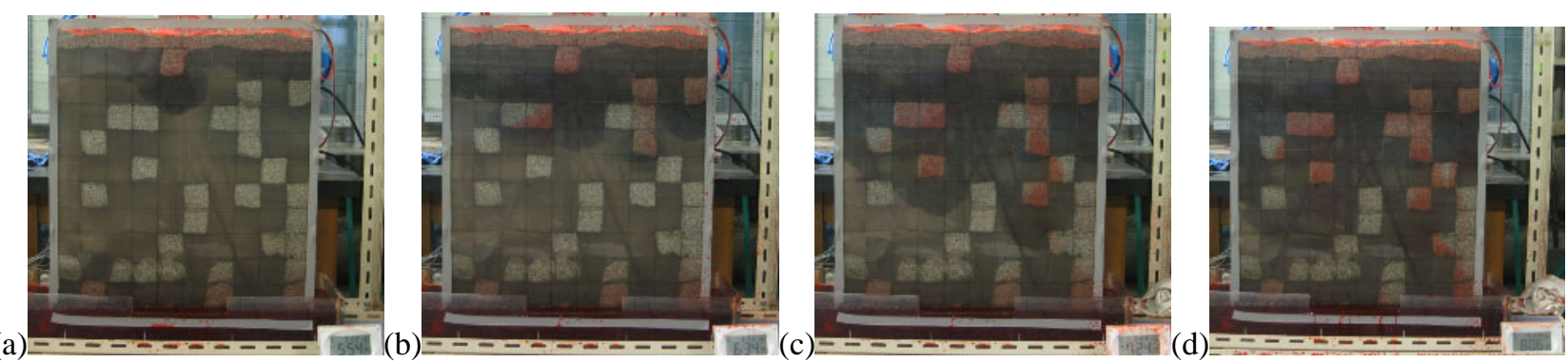

図- 8 実験Bにおける着色した水道水の浸透挙動 (a) 24 min., (b) 64 min., (c) 114 min., (d) 156 min.

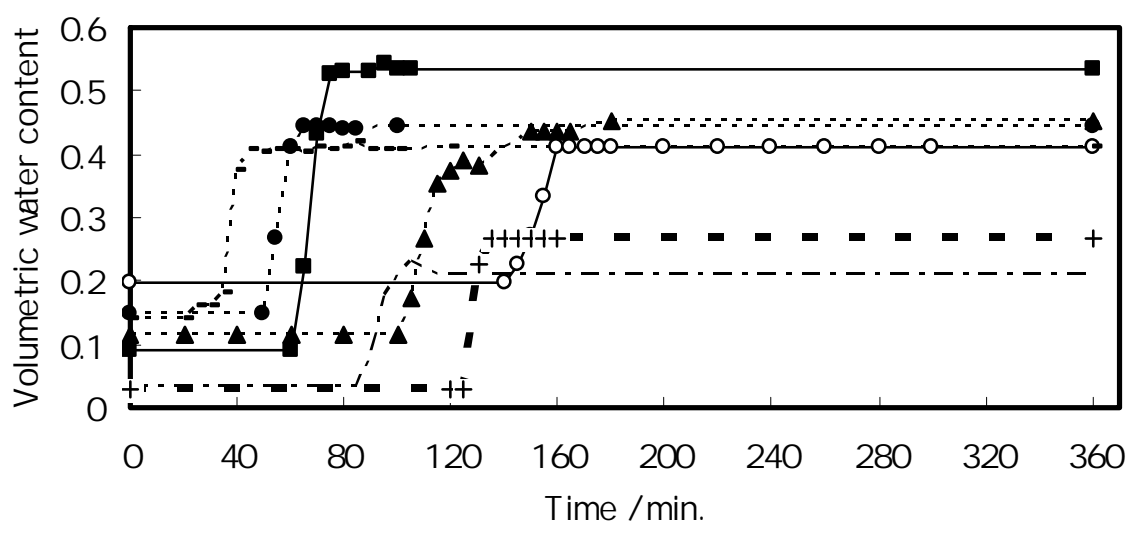

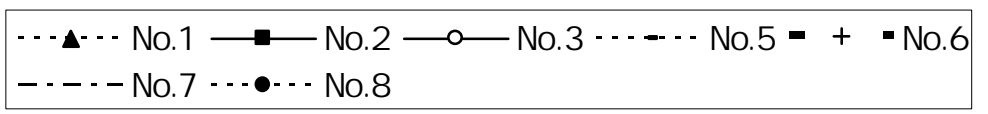

图- 9 実験BにおけるPCBP挿入点の体積含水率の变化
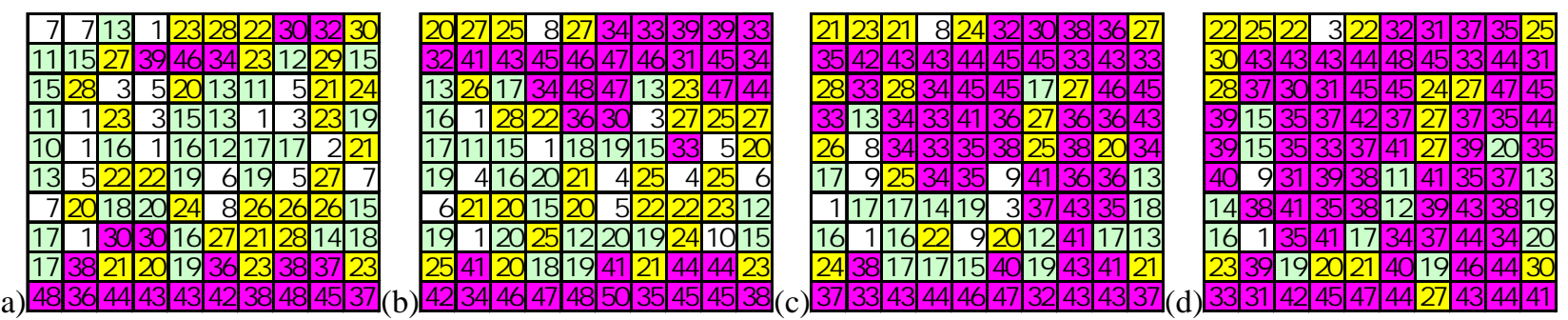

$\square>30 \% \square 20-30 \%$

10- $20 \% \square<10 \%$

図-10 実験BにおけるG值により推定した体積含水率分布の変化(\%表示) (a) 24 min., (b) 64 min., (c) 114 min., (d) 156 min.

No.1〜 5の挿入点は農場廃土試料であり，湛水によ り投入された水道水が到達した後は, 高い水分量で 推移していることが分かる.No.5は浸透が先行する 凸部の右下に位置し，ただちに水分上昇が起こって おり，TDRによる計測が正しく行われていることが 確認できる . No.2と8の点は, 浸透層上部の同じ高 さに位置している . 1, 2回目の湛水に対しては, 若 干No.2の方が早く水分上昇が起こっており，左右対 称というより左側が早く浸透が進んでいることが分 かる.このことは図 5 (a)からも推定できる.2回目 の湛水に対応した水分上昇は，No.1と8で，ほぼ同 時に起こっており，兴の後の変化も概ね同じである． No.2, 8の最初のピークは, 実験開始後 40 分に最初 のピークが表れている . 浸透層中央部のNo.4では , 記録した波形が解析不能で, 初期のデータが欠損し ているが, 実験開始後 120 分以降の変化は, 湛水へ の応答を示しつつ, 3 回目の湛水直後まではNo.2と 同樣の, 光れ以降は, No.1, 8とほぼ同樣の変化を示
した .よって, 先行して浸透した中央部の影響を受 けて，初めの方では上部のNo.2と同じ変化をするが， 時間がたてば左側の浸潤前線が追いついてきてほぼ 平行に浸透が進むようになったと考えられる . 中央 部下部のNo.3においては, 初期の体積含水率が $20 \%$ となっており，これは浸透層下端に設けた水面から の毛管上昇と, 重力排水により上部から移動してき た水分を保水したためと考えられる.水分の上昇は 緩やかであるが, 3 回目以降の湛水には応答してい ることが分かる.いずれのPCBP挿入点においても， 湛水への応答はただちに表れているので，これは押 し出しによる水分の上昇であると考えられる.

図-7には, 図-5に対応するG值により推定された 体積含水率分布の変化を示す. 実験写真と比較する と，水分量の多少は概ね良好に再現できたと考えら れる.浸透層最下段で体積含水率が高くなっている のは, 水面からの毛管上昇を再現できたものと考え られる．TDRによる測定との対応を見てみると， 
No.6や7の部分では低い水分量となっており，概ね 正しく推定できていると考えられる .

(2) 降雨発生装置による浸透実験 (実験B)

図-8に実験Bにおける着色した水道水の浸透挙動 を示す.実験 $\mathrm{A}$ 同樣，下に凸形の部分に先行し， 全体としては浸透層の右側を優先的に流下した . 透 水係数の分布が同じであれば，水の浸透する経路光 のものはあまり変わらないようである .

图-9にPCBPを用いたTDRによる各測定点の体積 含水率の変化を示す .なおNo.4のプローブによる測 定は，波形が正しくとれなかったため示していない， 連続的に模擬降雨を与えたため, 実験 $\mathrm{A}$ 異なり, 一旦保水されると，ほぼとのまま水分量を保ってい ることが分かる．水分量が上昇し，すぐに低下しな いのは，下部や側方への排水よりも早く，連続的に 上部から補給されるためと考えられる . 実験Aと同 樣, 砂が充填されているNo.6と7の測定点において は，他の点と比べ保水性は低くなっている．水分上 昇の順番は，No.5> 8>2>7>1>6>3となっている. すなわち，実験Aと同樣，凸部の右下であるNo.5で 先行して水分上昇が起こり，同じ高さでは右側が先 行して水分の上昇が起こっている $(8>2,7>1,6>3)$. この結果は図-8の実験写真とも相違せず，TDRによ る計測がほぼ正しく行われたことを示している. No.3においては, 実験 $\mathrm{A} と$ 同樣に, 下部の水面から の毛管上昇により初期の体積含水率が $20 \%$ となって

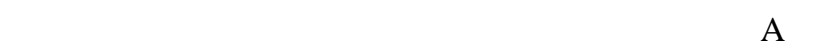
No.3のブロックの初期水分量は, 毛管上昇のみに起 因すると考えられる .

図-10には，図-8に対応するG值により推定された 体積含水率分布の変化を示す .これについても実験 Aと同樣に，概ね保持している水分量の多少を表現 できていると考えられる.実験終了後に, ブロック 毎に体積含水率を実測し, 提案している方法で推定 した体積含水率と比較したところ，ほぼ再現できた 今後 , 浸透層表面の反射による誤差などを補正する 方法を検討し，より適用可能性を高めたいと考えて いる。

\section{6 .おわりに}

本研究では, 飽和透水係数が不均一に分布する浸 透層を対象とし，初期に所定の水分量に調整した浸 透層へ, 上部より着色した水道水を段階的に湛水し 浸透させる実験と，同樣に着色した水道水を降雨発 生装置により連続的に浸透させる実験を行った。光 の結果，いずれの実験においても，水は透水性の大 きいブロックを多く配置した右側壁面下部へ向かっ て選択的に流下した．PCBPを用いたTDRによる土 壤水分変化の測定によれば, 段階的湛水実験 (実験 A)では, 土猿水分増加が, 湛水のタイミングによく 応答しており，浸潤前線が到達した後の水分上昇は 押し出しによるものと考えられた . また連続的な降 雨発生装置による実験 (実験B)では，実験 $\mathrm{A}$ と異な
り一旦水分が上昇した後は, 保水し続けることが確 認できた . 水分上昇の順番は，実験写真とよく整合 した .いずれの実験においてもPCBPを用いたTDR による水分測定が概ね正しく行われたことが分かっ た. 本研究ではまた, 非破壊で簡便な土壌水分の推 定方法として実験写真の画像解析により抽出された G值によって推定する方法を提案した .いずれの実 験においても水分量の多少は概ね正しく推定できた と考えられる .

PCBPを用いたTDR法による測定は，局所的な土 壤水分の時間変化を捉えるのに適していると考えら れる.一方，画像解析による推定は，実験における 浸透層全体の土壌水分分布を把握するのに適してい ると考えられ，両者を組み合わせる方法で，現象の 解明に役立てることができると考える .

\section{参考文献}

1) Mantoglou, A.: A theoretical approach for modeling unsaturated flow in spatially variable soils: effective flow models in finite domains and nonstationary, Water Resources Research, Vol.28, No.1, pp.251-267, 1992.

2) Jensen, K.H. and Mantoglou, A: Application of stochastic unsaturated flow theory, numerical simulations, and comparisons to field observations, Water Resources Research, Vol.28, No.1, pp.269-284, 1992.

3) Yeh, T.-C.J. and Harvey, D.J.: Effective unsaturated hydraulic conductivity of layered sands, Water Resources Research, Vol.26, No.6, pp.1271-1279, 1990.

4) Wildenschild, D. and Jensen, K.H.: Laboratory investigations of effective flow behavior in unsaturated heterogeneous sands, Water Resources Research, Vol.35, No.1, pp.17-27, 1999.

5) Wildenschild, D. and Jensen, K.H.: Numerical modeling of observed effective flow behavior in unsaturated heterogeneous sands, Water Resources Research, Vol.35, No.1, 29-42, 1999.

6) 中川 啓·岩田将英 - 筑紫二郎 - 籵井和朗 : 不飽和 不均一多孔媒体における物質輸送特性について, 水工 学論文集, Vol.47, pp.337-342, 2003.

7) Chiang, W.-H. and Kinzelbach, W.: 3D-Groundwater Modeling PMWIN, Springer-Verlag, Heidelberg, Germany, 2001.

8) Wang, W., Kobayashi, T. and Chikushi, J.: Measuring the Layer-Average Volumetric Water Content in the Uppermost $5 \mathrm{~cm}$ of Soil Using Printed Circuit Board TDR Probes, Journal of Faculty of Agriculture, Kyusyu University, Vol.45, No.1, pp.277-287, 2000.

9) Or, D., Jones, S.B., VanShaar, J.R., Humphries, S. and Koberstein, L.: WinTDR Users Guide, Utah State University, Plants, Soils, \& Biometeorology, Logan, Utah, 2003.

10) Evett, S.R.: Soil Water Measurment by Time Domain Reflectometry, Encyclopedia of Water Science, Marcel Dekker, New York, pp.894-898, 2003.

11) Topp, G.C., Davis, J.L. and Annan, A.P.: Electromagnetic determination of soil water content: Measurement in coaxial transmission lines, Water Resources Research, Vol.16, No.3, pp.574-582, 1980.

12) Persson, M.: Estimating surface soil moisture from soil color using image analysis, Vadose Zone Journal, Vol.16, pp.1119-1122, 2005.

(2006. 9. 30受付) 